\title{
MENGENAL JENIS-JENIS RUMAH INSTAN DI INDONESIA DAN KENDALA YANG DIHADAPI DALAM MEMASARKANNYA
}

\author{
Andi Prasetiyo Wibowo \\ Program Studi Arsitektur, Fakultas Teknik, Universitas Atma Jaya Yogyakarta \\ Surel: andi.prasetiyo@uajy.ac.id
}

\begin{abstract}
A house is a building that functions as a residence and the facility for family fostering. House construction is inseparable from the needs of construction materials. Calculation of the amount of material used on a project greatly affects the amount of the budget spent. There needs to be innovations that help house building process become more efficient both in time and cost. At present there are many home construction systems that have been developed using non-conventional methods. Comparison between the use of conventional materials with printed materials is that printed houses have better performance and effectiveness compared to conventional materials due to time savings and implementation costs, but with quality that is in accordance with established standards. RISHA (Rumah Instan Sederhana Sehat), one of the initiators of the concept of prefabricated modular houses in Indonesia is expected to be able to answer the aforementioned problem as a method of constructing non-conventional houses. However, the lack of information and outreach resulted in many people not understanding the concept and implementation of this type of building. The lack of an applicator is one of many factors preventing the development and application of instant home building to progress rapidly. Instant housing with all its advantages possesses good economic value when mass produced, such as post-disaster housing construction. However, this condition backfires on the view of the community who sees that instant houses are meant for the poor or those affected by a disaster. Social factor becomse a problem in promoting this product.
\end{abstract}

Keywords: RISHA, instant home, non-conventional, modular

\begin{abstract}
ABSTRAK
Rumah adalah bangunan yang berfungsi sebagai tempat tinggal atau hunian dan sarana binaan keluarga. Pembangunan rumah tidak terlepas dari kebutuhan material / bahan bangunan. Penentuan material yang digunakan pada suatu proyek sangat mempengaruhi besarnya anggaran yang dikeluarkan. Perlu adanya inovasi yang membuat proses pembanguan rumah menjadi lebih efisien baik secara waktu dan biaya. Saat ini telah banyak dikembangkan sistem pembangunan rumah dengn metode non-konvensional. Perbandingan antara penggunaan material konvensional dengan material cetak dapat dikatakan rumah cetak memiliki kinerja dan efektivitas yang lebih baik dibandingkan dengan material konvensional karena terjadi penghematan waktu dan biaya pelaksanaan namun mutu dan kualitas yang diperoleh sesuai dengan standar yang ditetapkan. RISHA (Rumah Instan Sederhana Sehat) yang merupakan salah satu dari penggagas konsep umah modular pre-fabrikassi di Indonesia diharapkan dapat menjawab permasalahan di atas sebagai salah metode pembangunan rumah non-konvensional. Namun, kurangnya informasi dan sosialisasi mengakibatkan banyak masyarakat yang kurang paham akan konsep dan implementasi bangunan jenis ini. Kurangnya aplikator menjadi salah satu faktor lain yang menyebabkan perkembangan dan penerapan bangunan rumah instan ini tidak berjalan dengan pesat. Rumah instan dengan segala kelebihannya mempunyai nilai ekonomis yang baik apabila diproduksi secara massal, seperti pembangunan rumah pasca bencana. Namun kondisi ini justru menjadi bumerang bagi pandangan masyarakat yang menganggap bahwa rumah instan untuk golongan tidak mampu atau terkena dampak bencana. Faktor sosial menjadi problem tersendiri dalam memasyarakatkan produk ini.
\end{abstract}

Kata kunci: RISHA, rumah instan, non-konvensional, modular

\section{PENDAHULUAN}




\section{Latar Belakang}

Rumah adalah bangunan yang berfungsi sebagai tempat tinggal atau hunian dan sarana binaan keluarga (Turner, 1982). Secara sosial rumah juga berfungsi sebagai status simbol dan ukuran kemakmuran, dan juga digunakan sebagai sarana investasi (Cahyana, 2002). Maslow menyusun hierarki kebutuhan manusia berkaitan dengan hunian / rumah berdasar tingkatan tertentu dimulai dari yang terbawah atau paling mendasar sebagai berikut :

a) Rumah dinilai memberikan perlindungan terhadap gangguan alam dan binatang yang berfungsi sebagai tempat tinggal, tidur, dan pemenuhan kebutuhan badani.

b) Rumah dinilai harus bisa menciptakan rasa aman, sebagai tempat menjalankan ritual, penyimpanan harta milik berharga, dan menjamin hak pribadi.

c) Rumah juga dinilai memberikan peluang untuk berinteraksi dan aktivitas komunikasi yang akrab dengan lingkungan sekitar (teman, tetangga, ataupun keluarga).

d) Rumah juga memberikan peluang untuk tumbuhnya harga diri, yang disebut Pedro Arrupe sebagai "Status Conferring Function", yakni kesuksesan seseorang tercermin dari rumah dan lingkungan tempat huniannya.

Rumah sebagai wadah aktualisasi diri yang diejawantahkan dalam bentuk pewadahan kreativitas dan pemberian makna bagi kehidupan yang mempribadi.

Dalam memilih rumah terdapat 5 faktor gaya hidup yang mempengaruhi, yaitu : Faktor sosial terdiri dari aktivitas sosial, komunitas, peristiwa masa depan, dan lokasi; Faktor rumah tangga terdiri dari keluarga, rumah, dan pekerjaan; Faktor kesenangan terdiri dari liburan, hiburan dan ekonomi; Faktor referensi terdiri dari media informasi, rekreasi, pendidikan dan budaya; Faktor identitas terdiri dari aktivitas bekerja dan selera desain (Listyorini, 2012)

Pembangunan rumah tidak terlepas dari kebutuhan material / bahan bangunan. Penentuan material yang digunakan pada suatu proyek sangat mempengaruhi besarnya anggaran yang dikeluarkan. Salah satu jenis pekerjaan yang memerlukan material yang banyak adalah pekerjaan dinding yaitu pasangan bata. Hasil analisis biaya dan waktu per $\mathrm{m} 2$ pada pekerjaan pasangan dinding menggunakan bata merah konvensional memerlukan biaya sebesar Rp 270.320,00 dengan waktu 13 menit dan pekerjaan pasangan dinding menggunakan bata ringan citicon memerlukan biaya sebesar Rp 214.147,00 dengan waktu 10 menit. (Diatmika, P. , 2015).

Istilah rumah instan kemudian muncul setelah adanya inovasi dari tim Puslitbangperkim yang menciptakan RISHA (Rumah Instan Sederhana Sehat). RISHA lahir pada tahun 2004 hasil inovasi tim dari Puslitbangperkim dan langsung diaplikasikan di Aceh sebanyak 11.000 unit shelter untuk menaungi warga korban bencana alam gempa bumi dan tsunami Aceh.

RISHA dikonsepkan sebagai rumah knockdown (dapat dibongkar pasang) sekaligus sebagai rumah tumbuh. Material utama RISHA merupakan struktur beton bertulan prefabrikasi yang terdiri dari 3 jenis komponen inti yang masing-masing bobotnya kurang dari $50 \mathrm{Kg}$. Dengan bobot yang relatif ringan tersebut, diharapkan RISHA menjadi bangunan yang ringan dan aman terhadap gempa. Teknologi RISHA walau sederhana, namun tetap memerlukan keahlian khusus. Pelaksana lapangan yang membangun RISHA dikenal dengan sebutan aplikator. Aplikator RISHA mulamula ada dan berkembang sekitar tahun 2004-2006. Saat itu masih di sekitar Aceh, dalam rangka pembangunan 11 ribu shelter hunian pasca bencana Aceh 2004. Saat itu masih ditemui kendala di mana kualitas beton sebagai komponen struktur utama RISHA yang sangat rendah. Di sini Puslitbangperkim selaku institusi yang meciptakan dan mengembangkan RISHA merasa bahwa teknologi yang dimilikinya ini harus dikawal terus sampai dengan tingkat yang mapan/stabil. Bangunan instan dapat lebih efisien jika menggunakan material fabrikasi, atau material yang dapat 
dibuat secara massal dalam pabrik (Noverti, 2014), namun saat itu kondisi kurang memungkinkan untuk membuat pabrik. Selain itu dengan memberdayakan "tenaga kerja" lokal, diharapkan kegiatan pencetakan komponen RISHA ini bisa memberikan penghasilan/mata pencaharian bagi warga setempat. Perlahan namun pasti beberapa aplikator akhirnya mampu memenuhi standar yang disyaratkan.

Peluang usaha sebagai aplikator RISHA sebenarnya masih sangat menjanjikan, mengingat kebutuhan rumah yang terus meningkat namun tidak diimbangi dengan pembangunan perumahan. Terlebih saat ini masyarakat masih banyak yang belum mengenal RISHA. Kalaupun ada yang sudah mengenal RISHA, namun karena terbatasnya jumlah aplikator, maka konsumen ini belum dapat terlayani. Dalam penelitiannya, Nugraha, D.H. (2010) menyimpulkan bahwa beberapa hal yang dianggap "mengganggu" efektifitas pemasaran dan pengembangan RISHA, antara lain yaitu RISHA yang dianggap masih relatif mahal, langkanya cetakan RISHA di pasaran, dan pengetahuan kompleks / "rumit" tentang RISHA

Saat ini aplikator RISHA sudah mempunyai asosiasi yang diberi nama APMARI (Asosiasi Pemberdaya Masyarakat RISHA Indonesia). Diharapkan dengan adanya asosiasi aplikator ini bisa saling mendukung dan memperluas jaringan penyebaran RISHA.

Untuk menjadi aplikator RISHA sebenarnya cukup mudah, mengajukan surat permohonan ke puslitbangperkim dan selanjutnya dengan kerjasama dengan aplikator rekanan atau melalui asosiasi, pemohon ini akan diberi pelatihan dan pendampingan.

Selain di Aceh, RISHA juga telah diaplikasikan di beberapa tempat lainya di antaranya :

1. Kampung deret Petogogan DKI Jakarta (RISHA 2 lantai dengan panel lantai menggunakan keraton)

2. Perkampungan Nelayan di Jepara (sekitar 50 unit)

3. Atambua (285 unit) program kerja Direktorat rumah khusus.

4. Penataan kawasan rumah tidak layak huni di Mauk Tangerang, kerjasama dengan INDOCEMENT (panel dinding)

\section{METODE PENELITIAN}

Dalam penulisan makalah ini menggunakan metode deskriptif dengan cara pengumpulan data sekunder melalui studi kepustakaan dan studi dokumen yaitu pengumpulan data yang berdasarkan pada hasil penelitian-penelitian yang berkaitan dengan pembangunan rumah sederhana, khususnya pembangunan rumah dengan sistem non-konvensional. Data yang diperoleh akan dianalisis secara kualitatif yaitu analisis yang dilakukan dengan memahami dan merangkai data yang telah dikumpulkan dan disusun secara sistematis kemudian ditarik kesimpulan.

\section{HASIL PENELITIAN DAN PEMBAHASAN}

Saat ini telah banyak dikembangkan sistem pembangunan rumah dengn metode non-konvensional. Perbandingan antara penggunaan material konvensional dengan material cetak dapat dikatakan rumah cetak memiliki kinerja dan efektivitas yang lebih baik dibandingkan dengan material konvensional karena terjadi penghematan waktu dan biaya pelaksanaan namun mutu dan kualitas yang diperoleh sesuai dengan standar yang ditetapkan. (Wahyudi, 2015). Perkembangan rumah instan yang terjadi saat ini banyak menghadirkan kompetitor-kompetitor dari RISHA yang sudah 
muncul lebih dulu. Perbandingan harga dan metode pembangunan dapat menjadi alternatif masyarakat untuk memilih produk yang sesuai.

\section{KOMPETITOR RISHA}

\section{BATATON}

Bataton merupakan produk beton preCast dari Holcim terkait program yang dikenal sebagai Solusi Rumah Holcim. Solusi rumah merupakan bisnis waralaba dalam proses pendampingan membangun rumah biasa, dengan Holcim dan mitra waralabanya sebagai konsultan. Holcim sebagai suplier bahan bangunannya (semen). Memang ada unsur instant di Solusi Rumah, tapi bukan rumah instan, melainkan bahan bangunan instan yang disebut 'bataton', bahan bangunan instant ini tak lain aneka komponen yang dibuat dengan sistem pracetak (precast). Mulai bataton untuk pondasi, tiang beton, sampai ke roster atau lubang angin.

Pihak waralaba dapat mencetak bataton ini secara mandiri namun dengan pengawasan dan kontrol dari pihak Holcim (dan tentunya menggunakan semen Holcim). Waralaba yang memproduksi komponen beton precast tersebut kemudian dikategorikan sebagai CPM (Concrete Product Manufacturing).

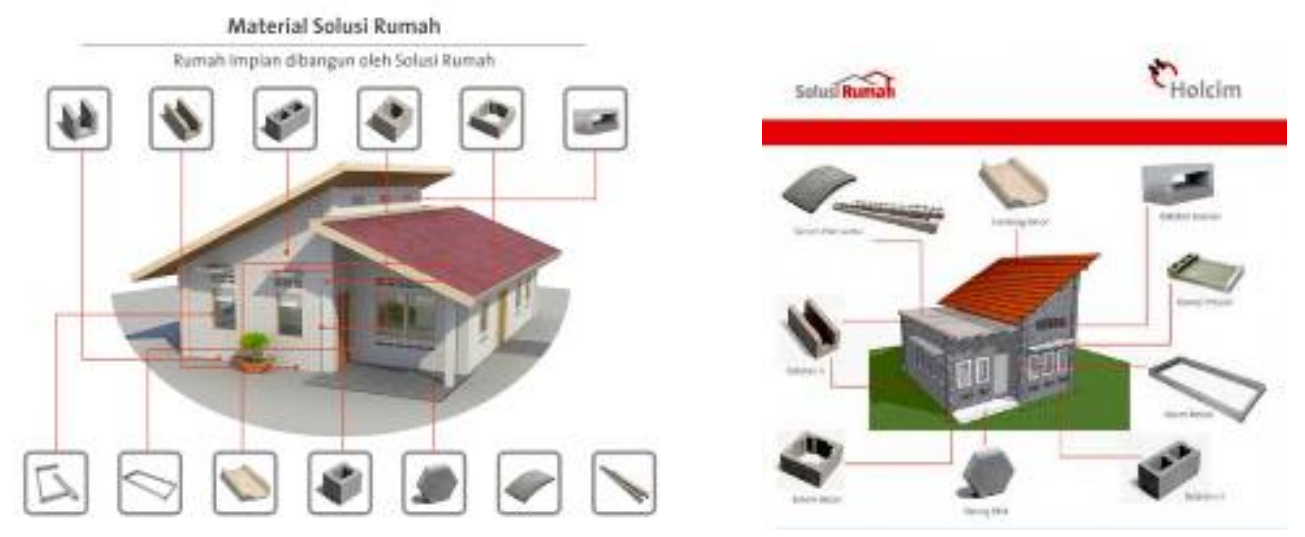

Gambar 1. Komponen Rumah dari Beton Precast Bataton

Satu hal yang bisa dipelajari dari konsep solusi rumah milik Holcim ini yaitu selain pendekatan kepada pihak pemodal (untuk diaajak kerjasama sebagai pewaralaba), konsep Solusi rumah yang manawarkan jasa konsultasi sekaligus pembangunan, dirasakan mampu membantu masyarakat di dalam menentukan dan memutuskan pembangunan rumahnya. Kerjasama dengan pihak bank yang bisa menyalurkan kredit pemilikan rumah menjadi penambah daya tarik masyarakat untuk datang ke solusi rumah dan menggunakan produk bataton ini.

"Kami sekaligus juga menghadirkan konsep pelayanan satu atap bagi para konsumen. Mulai dari perencanaan bangunan, pembiayaan serta pembangunan, bisa didapatkan melalui gerai ini. Kami juga menjalin kerja sama dengan pihak perbankan dalam menyediakan fasilitas Kredit perumahan Rakyat (KPR)". (http://srsalatiga.blogspot.co.id/2016/08/solusi-rumah-holcim-hadir-disalatiga.html). Sebagai peluang usaha, bisnis solusi rumah Holcim ini cukup menjanjikan dnegan modal $\mathrm{Rp} 50$ Juta, Bisa Miliki Waralaba Holcim (https://finance.detik.com/peluangusaha/1368085/modal-rp-50-juta-bisa-miliki-waralaba-holcim ; 02 Jun 2010)

\section{DOMUS}


Domus merupakan konsep rumah instan yang diproduksi oleh PT. TATA LOGAM LESTARI. Komponen utama (sruktur) dari Domus terbuat dari logam antikarat. DOMUS mulai diperkenalkan sejak November 2015 di JCC Jakarta saat ada perhelatan acara REI Ekspo (Ismayanto, 2015). Domus walaupun rumah instan, namun secara prinsip merupakan rumah permanen yang tidak bisa dibongkar pasang. Lama Waktu Pengerjaan tergantung dari tipe rumahnya, (Pitoko, 2016)

- $\quad$ Tipe $21=5$ hari

- $\quad$ Tipe $29=10$ hari

- $\quad$ Tipe $36=14$ hari

- $\quad$ Tipe $45=21$ hari

Sedangkan untuk harganya, terdapat 3 jenis pemaketan yaitu : PAKET RANGKA $=$ Rp 1.950.000,- / m2; PAKET PUTIH = Rp 2.850.000,- / m2; PAKET CANTIK = Rp 3.250.000,- / $\mathrm{m} 2$.

\section{CATATAN.}

1. Harga Item tidak termasuk pondasi dan cor lantai.

2. Harga Item tidak termasuk septictank.

3. Harga Item tidak termasuk saluran pembuangan / paret

4. Harga belum termasuk PPN $10 \%$

5. Harga dapat berubah sewaktu - waktu

(Wardana, 2017)

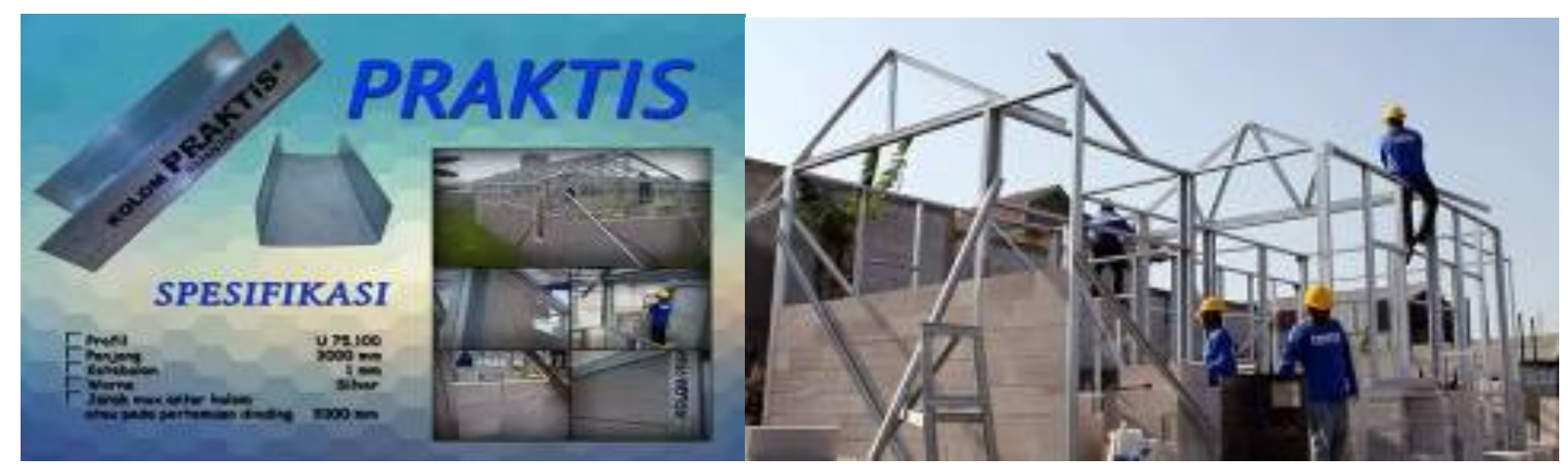

Gambar 2. Struktur utama DOMUS berbahan dasar logam antikarat

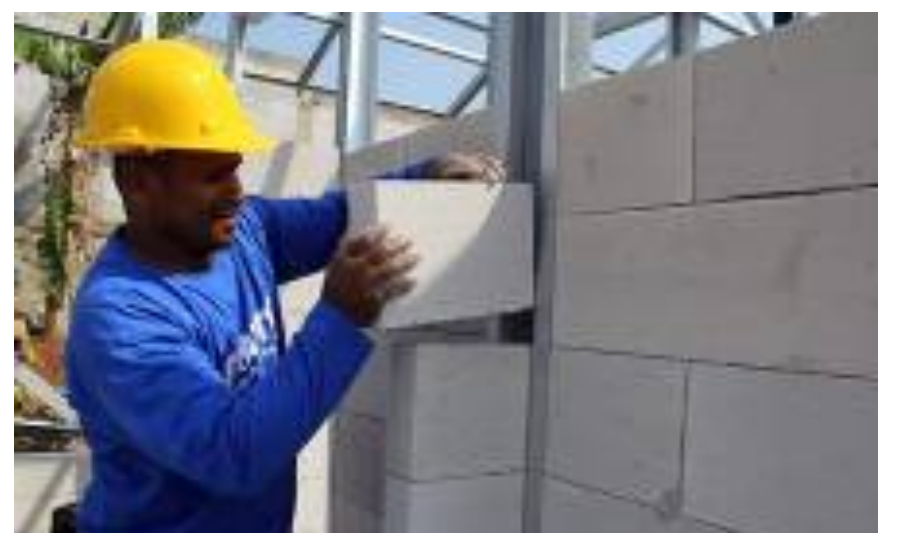

Gambar 3. Dinding DOMUS menggunakan bata ringan 


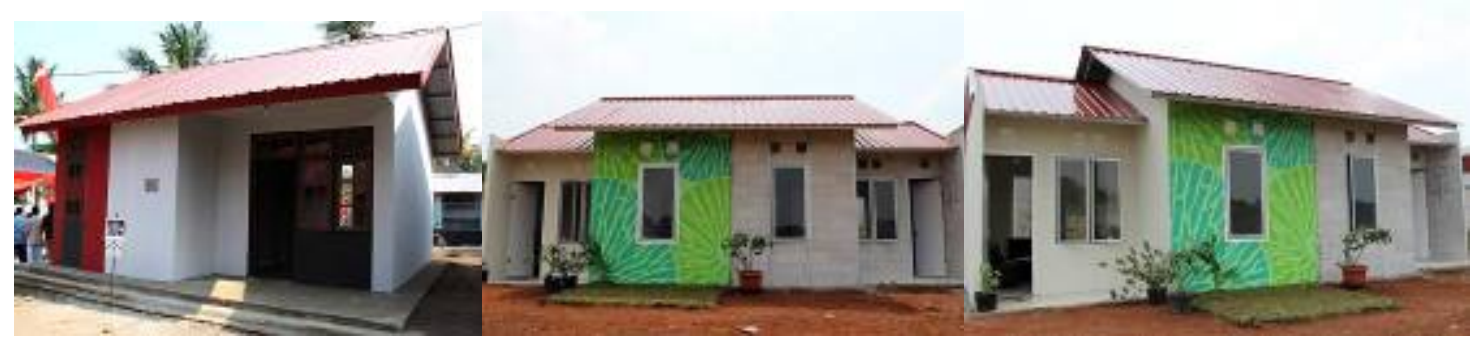

Gambar 4. DOMUS 1 lantai

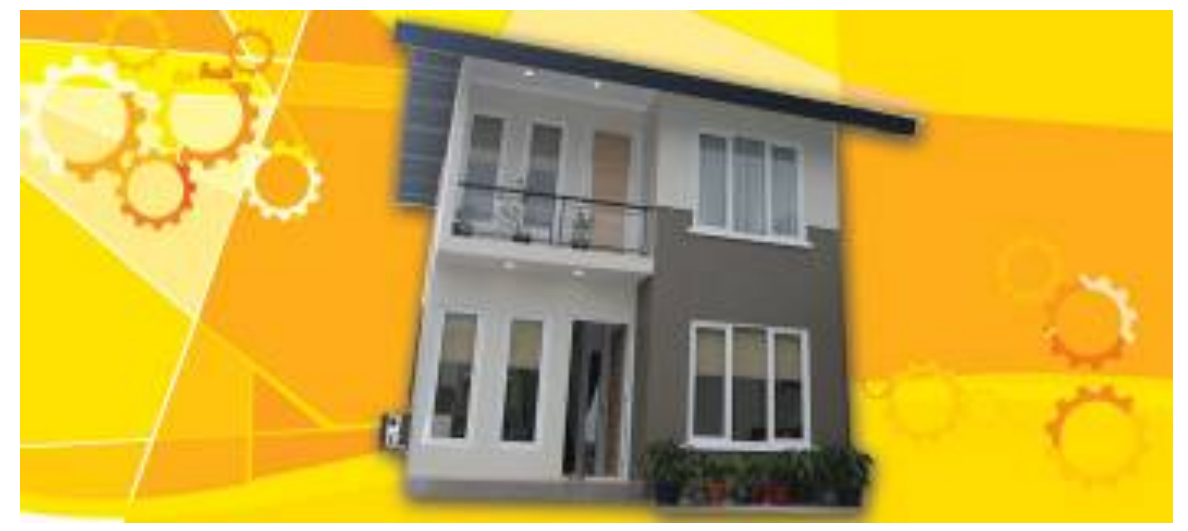

Gambar 5. DOMUS 2 lantai

\section{INDOSTAR}

Indostar Modular Sentral adalah perusahaan yang bergerak dalam bidang konstruksi rumah moduler. Kami memproduksi rumah moduler prefabrikasi yang merupakan rumah dengan desain dan material khusus sehingga dapat dirangkai dengan cepat kemudian dapat dibongkar kembali untuk dapat di bangun di tempat yang lain (http://www.indostarmoduler.com)

Harga Rumah Modular (FoB Semarang) :

- Bangunan Satu Lantai $: 2.150 .000 / \mathrm{m}^{2}$

- Bangunan Dua Lantai $: 2.500 .000 / \mathrm{m}^{2}$

- Bangunan Tiga Lantai $: 3.000 .000 / \mathrm{m}^{2}$

Biaya tersebut diatas sudah termasuk fisik bangunan beserta rangkaian listrik dan saluran air bersih dan kotor di dalam bangunan. Biaya di atas belum termasuk :

- PPN

- Biaya Pengiriman Komponen Bangunan ( Untuk Area di Luar Kota Semarang ).

- Transportasi, Akomodasi, dan penginapan Tenaga Ahli/ Supervisi ( Untuk Area di Luar Kota Semarang ).

- Penambahan/ Penggantian spesifikasi bangunan (by request).

- Harga di atas belum termasuk :

- Penyambungan akses air ke PDAM.

- Septic Tank. 
- Penyambungan listrik ke PLN.

- Pengurusan IMB.

Indostar menggunakan material untuk membangun rumah moduler dengan spesifikasi sebagai berikut :

Tabel 1. Spesifikasi Rumah Indostar

\begin{tabular}{|c|c|c|}
\hline Material & Spesifikasi & Keterangan \\
\hline \multirow[t]{3}{*}{ Panel Tembok } & Ketebalan & $\begin{array}{l}75 \mathrm{~mm} \text { pada ukuran standar untuk Dinding } \\
\text { Luar,dan } 100 \mathrm{~mm} \text { untuk dinding dalam. } \\
\text { (dapat diubah sesuai permintaan) }\end{array}$ \\
\hline & Tinggi & $\begin{array}{l}3000 \mathrm{~mm} \text { per lantai pada ukuran standar atau } \\
\text { bisa lebih (harga menyesuaikan). }\end{array}$ \\
\hline & Lebar & $600 \mathrm{~mm}$ pada ukuran standar. \\
\hline \multirow[t]{4}{*}{ Frame Pintu } & Daun Pintu & Pintu star door. \\
\hline & Ketebalan & $\begin{array}{l}\text { Rangka Aluminium dengan ketebalan } 40 \\
\text { mm. }\end{array}$ \\
\hline & Tinggi & $2100 \mathrm{~mm}$ pada ukuran standar. \\
\hline & Lebar & $830 \mathrm{~mm}$ pada ukuran standar. \\
\hline \multirow[t]{3}{*}{ Frame Jendela. } & Ketebalan & $\begin{array}{l}\text { Rangka Aluminium dengan ketebalan } 50 \\
\text { mm. }\end{array}$ \\
\hline & Panjang & $1200 \mathrm{~mm}$ pada ukuran standar. \\
\hline & Lebar & $1200 \mathrm{~mm}$ pada ukuran standar. \\
\hline Permukaan atas dan bawah Panel & & $6 \mathrm{~mm}$ fiber panel semen. \\
\hline Isi panel & & Busa semen. \\
\hline
\end{tabular}




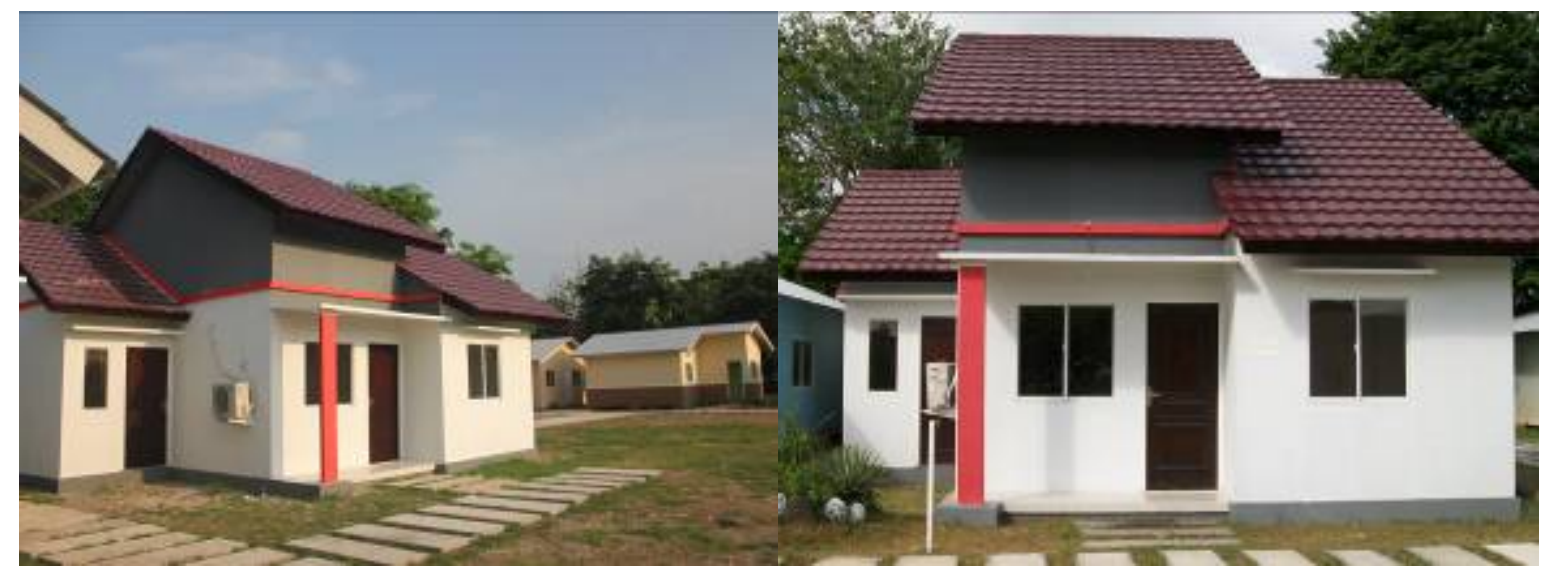

Gambar 6. Rumah Modular Indostar
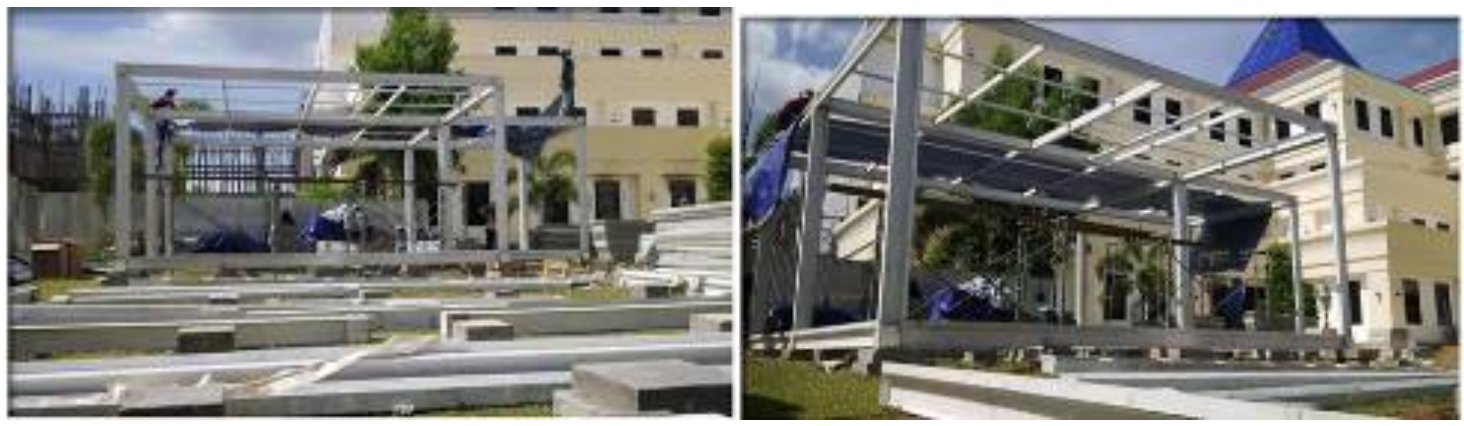

Gambar 7. Aplikasi Bangunan Modular Indostar di Kompleks Kantor Gubernur Maluku

Selain rumah dan bangunan modular permanen, Indostar juga memounyai produk rumah instan yang dapat dengan mudah dipindah atau dalam bentuk portabel.

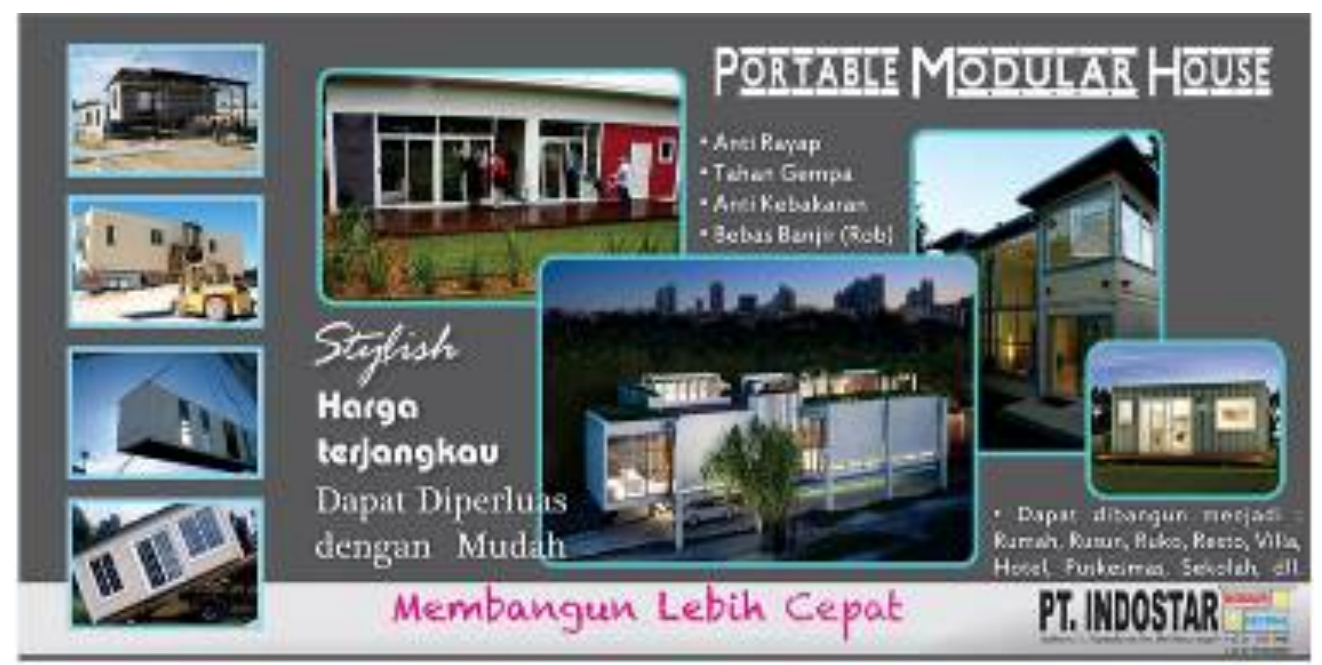

Gambar 8. Portable Modular House by PT. INDOSTAR

\section{KESIMPULAN DAN SARAN}


Perkembangan rumah instan di Indonesia yang saat ini banyak dikenal di masyarakat, jika dilihat dari bahan / struktur utamanya terdiri dari 2 jenis yaitu yang pertama rumah instan berbasis beton seperti RISHA dan rumah Holcim, dan rumah instan yang berbasis logam seperti yang dikembangkan tatalogam dengan produknya domus dan indostar. RISHA dan rumah instan lainnya memiliki daya tarik bisnis karena efektivitas dan biaya produksi yang cukup ringan apalagi jika akan diproduksi secara massal. Namun, kurangnya informasi dan sosialisasi mengakibatkan banyak masyarakat yang kurang paham akan konsep dan implementasi bangunan jenis ini. Kurangnya aplikator menjadi salah satu faktor lain yang menyebabkan perkembangan dan penerapan bangunan rumah instan ini tidak berjalan dengan pesat.

\section{REFERENSI}

Diatmika, P. (2015). PERBANDINGAN BIAYA DAN WAKTU PELAKSANAAN PEKERJAAN ANTARA BATA MERAH KONVENSIONAL DAN BATA RINGAN CITICON SEBAGAI DINDING PEMISAH RUANG (Doctoral dissertation, Universitas Udayana).

Ismayanto, Darma. 2015. Rumah Instan Permanen ini Hanya Rp 40 juta. http://www.rumahku.com/artikel/read/rumah-instan-permanen-ini-hanya-rp-40-juta412338/2. Diakses tanggal 15 Maret 2018

Listyorini, S. (2012). Analisis faktor-faktor gaya hidup dan pengaruhnya terhadap pembelian rumah sehat sederhana (Studi pada pelanggan perumahan Puri Dinar Mas PT. Ajisaka di Semarang). Jurnal Administrasi Bisnis, 1(1).

Nugraha, D. H. (2010). PERSPEKTIF SOSIAL EKONOMI TERHADAP APLIKASI TEKNOLOGI RUMAH RISHA. Jurnal Sosial Ekonomi Pekerjaan Umum, 2(1).

Noverti, R. S., Purwono, E. H., \& Martiningrum, I. (2014). Perancangan Bangunan Instan Fabrikasi. Jurnal Mahasiswa Jurusan Arsitektur, 2(2).

PY, R. R., \& Unas, S. E. (2015). Analisa Produktivitas Pekerjaan Dinding Panel, Dinding Batu Bata Konvensional, Dan Sni Pekerjaan Dinding. Jurnal Mahasiswa Jurusan Teknik Sipil, 1(2), pp-243.

Pitoko, Ridwan Aji. 2016. Biaya Bangun Rumah Permanen Domus Rp 19 Juta Saja. https://properti.kompas.com/read/2016/05/26/114005521/biaya.bangun.rumah.permanen.d omus.rp.19.juta.saja. Diakses tanggal 15 Maret 2018

Wahyudi, I., Djakfar, L., \& Rachmansyah, A. (2015). PENGARUH PENGGUNAAN MATERIAL CETAK TERHADAP WAKTU DAN BIAYA PROYEK PEMBANGUNAN RUMAH SEJAHTERA TAPAK (RST). Media Teknik Sipil, 12(2).

Wardana, Ali. 2017. Daftar Harga Rumah Instan Permanen (Domus). https://rumahinstan.com/blog/default-post.html. diakses tanggal 1 April 2018 